光照射によるチロシン,トリプトファン水溶液の 黄褐娈につレて（第 2 報）

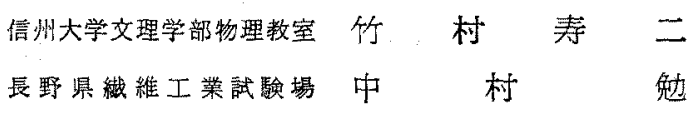

\title{
STUDIES ON THE YELLOWING OF TYROSINE, TRYPTPHANE AND THEIR MIXED SOLUTION BY EXPOSING TO LIGHT (PART II)
}

\author{
By Toshiji Takemura
}

(Department of Physics, Faculty of Liberal Arts and Science, Shinshu University, Matsumoto City, Japan)

\section{Tsutomu Nakamura}

(Textile Research Institute of Nagano Prefecture, Matsumoto City, Japan)

The previous paper (Part I) was reported on the yellowing of tyrosine, tryptphane and their mixed solution exposed to light within the range of $20 \sim 80 \mathrm{hrs}$.

In the present paper, an attempt is made to study on the yellowing of each solution mentioned above, by exposing to light for various time of $0 \sim 20 \mathrm{hrs}$., and the following results are obtained.

By comparison with the spectral optical density of each solution, it is found that the coloring processes of the mixed solution by light may be classified into the fallowing three periods;

In the first period $(0 \sim 5 \mathrm{hrs}$.), the coloring of tryptphane are scarcely recognized under the influence of tyrosine.

In the second period ( $5 \sim 10 \mathrm{hrs}$ ), the sensitization with respect to the visible light absorption appears rapidly at the short wave side.

In the third period $(10 \sim 20 \mathrm{hrs}$.), it proceeds slowly at the long wave side.

Considering the above facts from the colorimetrical point of view, the dominant wavelength of the mixed solution shifts from 573.0 to $575.5 \mathrm{m \mu}$.

The coloring phenomena of the silk stuffs are similar with the mixed solution : both the dominant wavelengths are between those of tyrosine and tryptphane.

In regard to the relation between transmittance $T(\%)$ of the mixed solution and exposure time $t$ (hr), the following formulae, which bear the same relation to the case of that by exposing for a longer time, are obtained.

$$
\begin{array}{ll}
T=a(t-k)^{-b} & (t>k+0.8) \\
T=100 \sim 98 & (t \leqq k+0.8) .
\end{array}
$$

Where the values of $k$; depending on the wavelength, vary 3 to 4 .

(Received October 23, 1963)

\section{1. 緒 言}

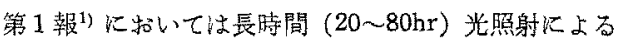
A 組試料の黄褐変について教察をしてきたが，これにつ ついて本報では短時間光照射による B 組陚料についての 瀴定結果括よびその考察を述べる。すなわちチロシン

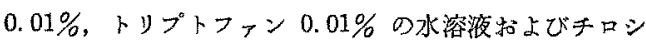

ン、トリプトファン各 $0.01 \%$ の混合水溶液に W. M. （ウェザー・オーメータ）火よる光て 5, 10, 15, 20hr

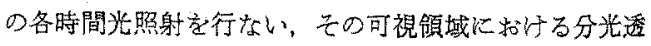
渦率 Beckman 型分光光電光度計で標準照明光源と して測り, 各溶液の黄褐変度を比較考察するむのてあ s。

貺定は1962 年 11 月中旬に行ない，照射前に和ける試 
第1表 溶液の吸光度 (1)

\begin{tabular}{|c|c|c|c|c|c|c|c|c|}
\hline \multirow{2}{*}{$\begin{array}{r}\text { 波長 } \\
(\mathrm{m} \mu)\end{array}$} & \multicolumn{4}{|c|}{$5 \mathrm{hr}$ 照 射 } & \multicolumn{4}{|c|}{$10 \mathrm{hr}$ 照 射 } \\
\hline & $D_{y}$ & $D_{r}$ & $D_{c}$ & $D_{c} / D_{s}$ & $D_{y}$ & $D_{r}$ & $D_{c}$ & $D_{c} / D_{s}$ \\
\hline 400 & 0.0044 & 0.0783 & 0.0292 & 0.4 & 0.0092 & 0.1518 & 0.2557 & 1.6 \\
\hline 420 & .0035 & .0477 & .0214 & $"$ & .0070 & .1051 & .1945 & 1.7 \\
\hline 440 & .0048 & .0334 & .0146 & $t$ & .0075 & .0815 & .1543 & $t t$ \\
\hline 460 & .0044 & .0273 & .0114 & $n$ & .0057 & .0680 & .1221 & $"$ \\
\hline 480 & .0048 & .0218 & .0110 & " & .0057 & .0575 & .1024 & 1.6 \\
\hline 500 & .0044 & .0155 & .0092 & 0.5 & .0052 & .0467 & .0836 & $" t$ \\
\hline 520 & .0044 & .0132 & .0092 & " & .0048 & .0395 & .0680 & 1.5 \\
\hline 540 & .0039 & .0106 & .0079 & $"$ & .0044 & .0334 & .0570 & $" \prime$ \\
\hline 560 & .0039 & .0092 & .0061 & " & .0044 & .0287 & .0472 & 1.4 \\
\hline 580 & .0035 & .0079 & .0057 & $" \prime$ & .0035 & .0255 & .0410 & $" \prime$ \\
\hline 600 & .0031 & .0048 & .0057 & 0.7 & .0031 & .0223 & .0357 & $"$ \\
\hline 620 & .0026 & .0048 & .0057 & 0.8 & .0026 & .0186 & .0283 & 1.3 \\
\hline 640 & .0026 & .0048 & .0052 & 0.7 & .0026 & .0177 & .0255 & $" \prime$ \\
\hline 660 & .0017 & .0048 & .0052 & 0.8 & .0017 & .0177 & .0227 & 1.2 \\
\hline
\end{tabular}

第 1 表 溶液の践光度 (2)

\begin{tabular}{|c|c|c|c|c|c|c|c|c|}
\hline \multirow{2}{*}{$\begin{array}{c}\text { 波長 } \\
(\mathrm{m} \mu)\end{array}$} & \multicolumn{4}{|c|}{$15 \mathrm{hr}$ 照 射 } & \multicolumn{4}{|c|}{$20 \mathrm{hr}$ 照 射 } \\
\hline & $D_{y}$ & $D_{r}$ & $D_{c}$ & $D_{c} / D_{s}$ & $D_{y}$ & $D_{r}$ & $D_{c}$ & $D_{c} / D_{s}$ \\
\hline 400 & 0.0200 & 0.1707 & 0.3028 & 1.6 & 0.0315 & 0.1911 & 0.3458 & 1.6 \\
\hline 420 & .0168 & .1163 & .2328 & 1.7 & .0273 & .1331 & .2700 & 1.7 \\
\hline 440 & .0137 & .0894 & .1891 & 1.8 & .0232 & .1024 & .2190 & $" \prime$ \\
\hline 460 & .0119 & .0726 & .1524 & $"$ & .0214 & .0799 & .1778 & $" \prime$ \\
\hline 480 & .0132 & .0595 & .1267 & 1.7 & .0223 & .0640 & .1457 & $"$ \\
\hline 500 & .0119 & .0477 & .1029 & " & .0186 & .0511 & .1186 & $" \prime$ \\
\hline 520 & .0132 & .0386 & .0873 & " & .0177 & .0419 & .0996 & " \\
\hline 540 & .0101 & .0329 & .0731 & $"$ & .0155 & .0348 & .0830 & $"$ \\
\hline 560 & .0092 & .0283 & .0630 & " & .0132 & .0292 & .0701 & " \\
\hline 580 & .0088 & .0237 & .0545 & $" 1$ & .0123 & .0227 & .0615 & $" \prime$ \\
\hline 600 & .0088 & .0182 & .0462 & $"$ & .0114 & .0186 & .0511 & $" \prime$ \\
\hline 620 & .0083 & .0155 & .0395 & $"$ & .0110 & .0150 & .0419 & 1.6 \\
\hline 640 & .0079 & .0146 & .0853 & 1.6 & .0106 & .0137 & .0381 & $"$ \\
\hline 660 & .0079 & .0146 & .0325 & 1.5 & .0101 & .0110 & .0339 & $"$ \\
\hline
\end{tabular}

またこれらの湘定値から透過光の 明度, 色度座熛, (刺激) 純度, 主 波長を $X Y Z$ 表色法の 30 選択分割 法により求めた結果は第 2 表のよう であり，色度図として园示したもの が第1图である。同因には参考とし て前々報々飞記入した綟布をW.M. で光照射したときの結果も記入して

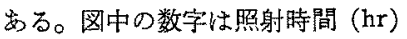
および主波長 $(\mathrm{m} \mu)$ を示す。第 2 表 の主波長の $1 \mathrm{~m} \mu$ 以下の值は測定精 度から考えて参教值として記入して 岕る。

\section{$2 \cdot 1$ 色相（主波長）についての 考察}

まずチロシン溶液については，同 じ濃度であるA組の場合と比較した とき，明度は大きく，純度は小さ い。例之浪A 組の $20 \mathrm{hr}$ 照射の試料 では明度 $95.89 \%$ ，純度 0.020 であ 万。

この相異は，括そらく $\mathrm{pH}$ のちが い(A組では 7.1) 扎よび温度の差 （A組では9月初旬测定）に起因寸 るすのと考党られる。

主波舆については，照射時間 15 hr までの試料でとくに純度が小 さいため，誤差が大きく入り易いの て記入をさけたが，20 hr 照射試料 では 576.4m从となり，A組の埸合 と一致する。

つぎにトリプトファン溶液はA 組 に比べ 5 倍の濃度であるために明度 は小さく純度は大きい。例壳ばA組 の $20 \mathrm{hr}$ 照射では明度 $98.50 \%$ ，純
料水溶液の pH 26.0 でる。測定の装置, 万法などは A組の場合と全く同様て岕り，第1報1を参照せられた wo

\section{2. 結果およひ考察}

各溶液の透過光の分光吸光度 $D$ を波長 $400 \sim 660 \mathrm{~m} \mu$ て $20 \mathrm{~m} \mu こ ゙ と に$ 测定した結果を第 1 表に示す。透過率 を $T(\%)$ とすれは $T$ と $D$ とは $\log _{10} T=2-D$ なる関保 によつて相互渻算することができる。表のなかで $D_{y}$, $D_{r} ， D_{c}$ はそれそれチャシン,トリプトファン敊よび混 合溶液の昅光度を示し， $D_{s}$ は $\left(D_{y}+D_{r}\right)$ である。
度 0.014 て方る。注意すべことは，主波長が照射時間 の增加てしたがつて，長波長側に移勒することでる。 このよ5なずれは照射時間 0〜20 hr で現われ，その後

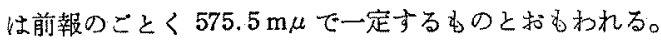
同じ現象が混合溶液の主波長についてもみられるが， このことは前報13.3 ですでに予想されたことである。

與昧のあること，網布の主波長もまた司じ傾向をも つている(第 1 図参照)。すなわら照射時間が $0,20,40$ $60 ， 100 ， 200 \mathrm{hr}$ で主波長はをれぞれ $572.7,574.5$, $574.7,575.3,575.6,575.9 \mathrm{~m} \mu$ と次第に長波長側に移 る。この傾可は貺定当初から気づいていたことで峛る 


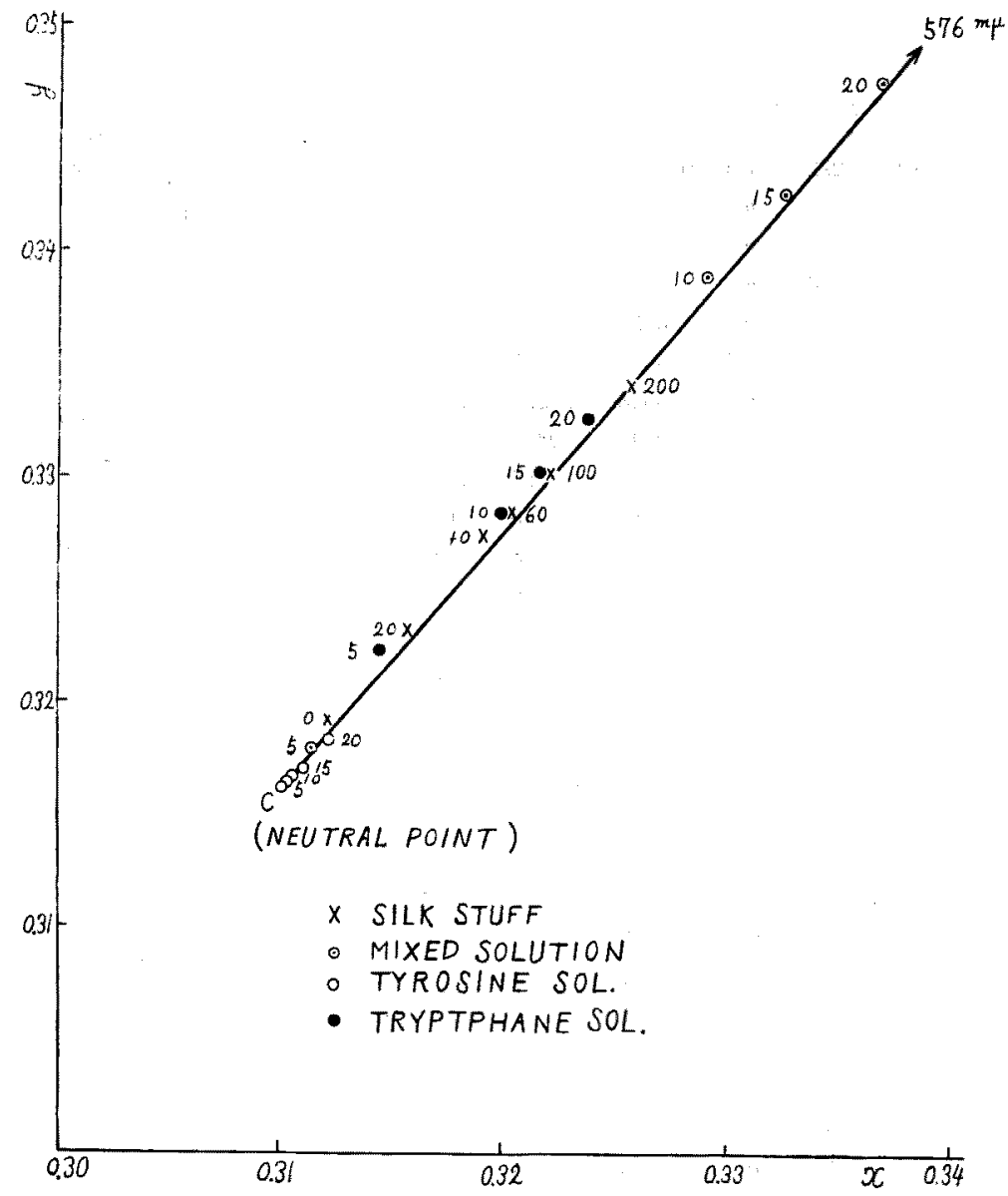

Fig. 1. Chromaticity diagram. Change of chromaticity with time of exposure which are represented by figures in hrs.

が，毛色点の近傍では主波長の愦差が大きくなりやす、 ことでるあり，いまずとくにこれを取りあげることを しなかつた。さて跼あるいは混合溶液において，主とな る発色物質がチロシン，トリプトファンのいずれである

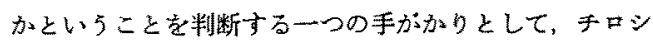
ン単独溶液にも短時間の光照射によつて主波長のずれが

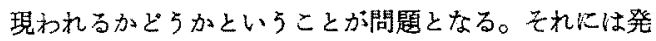
色の濃度索きらに大きくすることが必要でるが，溶液 の濃度を $0.01 \%$ 以上飞することは溶解度から見てはな

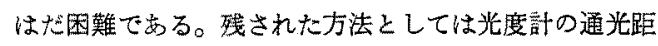
離を長くすることが考えられる。著者らは徒来の $1 \mathrm{~cm}$ の吸収液槽の代りに $5 \mathrm{~cm}$ の長吸收管学使用して $0.01 \%$ チロシン我溶液の黄褐変化を測定したところ, 主波長の ずれはトリプトフォンに比較して少なく, 574〜 576. $4 \mathrm{~m} \mu$
という結果を得た。湿合溶液の主波長はつね视雨者の主 波唇の中間で、トリプトファンにきわめて近いとこるに あることがわかる。

\section{$2 \cdot 2$ 混合溶液の発色增感および減感作用}

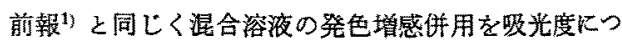
いて考察する。混合溶液の吸光度む $D_{c}$ とし，チロシン トリプトファン各単独溶液の吸光度 $D_{y}, D_{\tau}$ の和を $D_{\mathrm{s}}$ とし， $D_{d} / D_{\mathrm{s}}$ 学和り発色增感率とです名つけるなら ば，第1表右らん示す上5に照射時間 $15 \mathrm{hr}$ $20 \mathrm{hr}$ でこの値は各波長について 1.6 1.8 (平坞值 1.7) でほぼ一定しているけれども，10 hr のものは長波链側

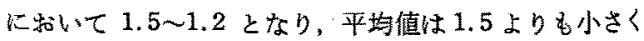
なつている。さらに $5 \mathrm{hr}$ のむのはすべて 1 よる小さ W(平均值 0.5 )。 
第 2 表 溶渵 0 黄褞变

\begin{tabular}{|c|c|c|c|c|c|c|}
\hline \multirow{2}{*}{ 試 料 } & \multirow{2}{*}{$\begin{array}{l}\text { 照射 } \\
\text { 時間 } \\
t(\mathrm{hr})\end{array}$} & \multirow{2}{*}{$\begin{array}{c}\text { 明度 } \\
Y(\%)\end{array}$} & \multicolumn{2}{|c|}{ 色度幽標。 } & \multirow{2}{*}{$\begin{array}{c}\text { 純度 } \\
p\end{array}$} & \multirow{2}{*}{$\begin{array}{l}\text { 主诐長 } \\
(\mathrm{m} \mu)\end{array}$} \\
\hline & & & $x$ & $y$ & & \\
\hline \multirow{4}{*}{$\begin{array}{l}\text { チ・ンン } \\
(0.01 \%)\end{array}$} & 5 & 99.14 & 0.3102 & 0.3163 & 0.0006 & - \\
\hline & 10 & 99.06 & 0.3107 & 0.3168 & 0.003 & - \\
\hline & 15 & 97.89 & 0.3110 & 0.3171 & 0.005 & - \\
\hline & 20 & 96.77 & 0.3121 & 0.3184 & 0.011 & 576.4 \\
\hline \multirow{4}{*}{ 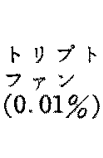 } & 5 & 97.45 & 0.3144 & 0.3224 & 0.028 & 572.7 \\
\hline & 10 & 92.84 & 0.3199 & 0.3284 & 0.058 & 574.6 \\
\hline & 15 & 92.99 & 0.3216 & 0.3302 & 0.068 & 574.9 \\
\hline & 20 & 92.77 & 0.3237 & 0.3326 & 0.081 & 575.2 \\
\hline \multirow{4}{*}{ 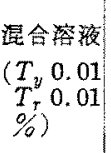 } & 5 & 98.50 & 0.3114 & 0.3180 & 0.008 & 573.0 \\
\hline & 10 & 88.60 & 0.3290 & 0.3388 & 0.110 & 575.2 \\
\hline & 15 & 85.47 & 0.3325 & 0.3425 & 0.130 & 575.4 \\
\hline & 20 & 83.77 & 0. 3369 & 0.3474 & 0.156 & 575.5 \\
\hline
\end{tabular}

すなわら発色增感率は光照射 5 10 hr ころからまず 短波長側に怙いて急激に大きくあられれ，芹の後は長波 長側が徐々飞增感されて 15 20hr で可視部全領域て ほ泳一定する。

しかしながら $D_{\boldsymbol{c}} / D_{\mathrm{s}}$ の值はさらに長時間光照射を行 ならことによつて，な增加するるのと考齐られ

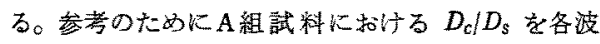
長の平均值として求めれば，照射時間 $20 ， 40 ， 60$, $80 \mathrm{hr}$ でれれそれ 1.5，2.0，2.3，3.2. と順次大き くな。最後の值がとくた大いのは，このときの $D_{y}, D_{r}$ は退色飞よつて $60 \mathrm{hr}$ 照射の場合上りる小

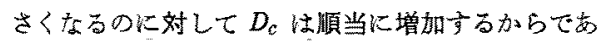
る(第 3 表参照)。

第了表 $\mathrm{A}$ 組武料に敌计る $D_{c} / D_{s}$ 值

\begin{tabular}{|c|c|c|c|c|}
\hline $\begin{array}{l}\text { 济 長 } \\
(\mathrm{m} \mu)\end{array}$ & $20 \mathrm{hr}$ & $40 \mathrm{hr}$ & $60 \mathrm{hr}$ & $80 \mathrm{hr}$ \\
\hline 400 & 1.6 & 2.0 & 2.0 & 3.2 \\
\hline 420 & 1.7 & $" \prime$ & 2.1 & 3.3 \\
\hline 440 & 1.6 & $" \prime$ & 2.2 & $"$ \\
\hline 460 & $" t$ & $" 1$ & 2.1 & 3.2 \\
\hline 480 & in & if & 2.0 & " \\
\hline 500 & $" \prime$ & 1.9 & 2.1 & 3.3 \\
\hline 520 & $"$ & 2.2 & 2.4 & $"$ \\
\hline 540 & $"$ & 2.0 & 2.2 & 3.1 \\
\hline 560 & 1.5 & $"$ & " & 3.3 \\
\hline 580 & "I & $" 1$ & 2.4 & $"$ \\
\hline 600 & 1.4 & $" \prime$ & 2.5 & 3.2 \\
\hline 620 & $t$ & $" t$ & $" \prime$ & $\prime \prime$ \\
\hline 640 & 1.3 & 2.1 & 2.7 & 3.0 \\
\hline 660 & 1.2 & 1.8 & 2.5 & 2.9 \\
\hline
\end{tabular}

$5 \mathrm{hr}$ 照射の場合の $D_{c}$ は各波長平均して $D_{s}$ の半分 に才ぎず，全波長を通じて透過率は 93.5 98.8\% では とんど無色透明である。なお $D_{r} / D_{v}$ の值を発色の主要 部分である 400〜 500 $\mathrm{m} \mu$ について求めれば平均值として 9となり、トリプトファンの级光度がチロシンに比べて 箸しく大きいことから，この期間におけるトリブトフっ ンの発色性がチロシンの存在に上つて，住 $1 / 2$ に抑制 されたものと考えてるよいであ万う。光照射の初期炕

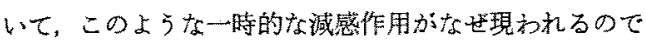
あろ5か。著者らは光化学反応法ける誘導期の上5な ものの存在を連想するのであるが，令後に残された問題 のーつである。

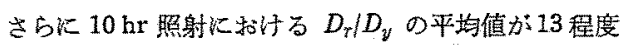
となることから，この期閏にお虰る泿合溶液の発色は子 ロシンの艺酸化生成物によつて，逆にトリプトファンが 増感される可能性がつよい。枯 $15 \mathrm{hr} の と き の D_{r} / D_{y}$

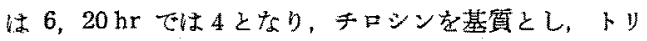
プトファンを增感剤とする音色 ${ }^{3 \sim 6)}$ 次第に奇与してく るるのと考党られる。

\section{$2 \cdot 3$ 透過率，明度と照射時間との関保}

混合溶液について透過率 $T(\%)$ 和よび透遗光の明度 $Y$ (\%) と照射時間 $t(\mathrm{hr})$ 之の間にA組の泥合溶液の皦合

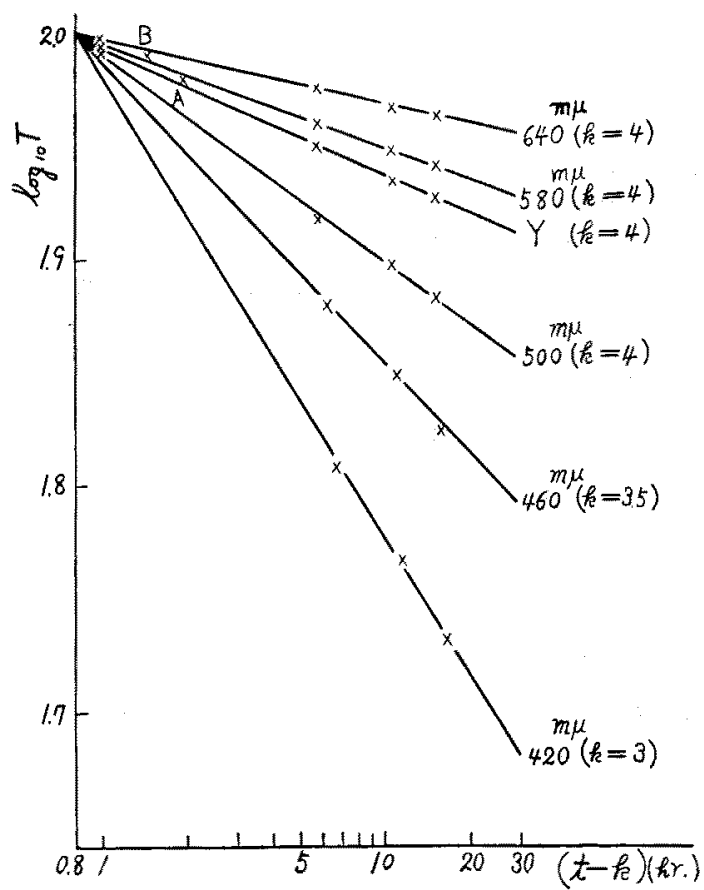

Fig. 2, Relations between transmittance $T(\%)$, luminosity $Y(\%)$ and time of exposure $t(\mathrm{hr})$. 
之同じ関係

$$
\begin{array}{ll}
T(\text { または } Y)=a(t-k)^{-b} & (t>k+0.8) \\
T(\text { または } Y)=100 \sim 98 & (t \leq k+0.8)
\end{array}
$$

が成立つ。ただしは波長定数で 400〜440m, 〜 480m $\mu$ ては 3.5, $500 \mathrm{~m} \mu$ 以上では 4 でする。 また下 の式の右辺を100〜98としたのは無照射試料の透遇彎が この範囲にあることる示す。

第 2 図はこの関係を図示したすのでたて軸に $\log _{10} T$ $=2-D を ， よ こ$ 軸に $\log _{10}(t-k)$ をとれば測点は直楾 となることを示したものである。

とくに $5 \mathrm{hr}$ 照射のものの短波長側の透過率は例外と してかなり大きい。図の点A，B はそれそれ波長 420 , $460 \mathrm{~m} \mu$ の透過率で岁る。こことは $5 \mathrm{hr}$ 照射では発 色減感作用が強く、まだ短波長側の吸収がほとんと現わ れていない状態であることを示するので，分光透過率曲 楾を描いてみれば明瞭に理解されるものである。

また $k$ の值がA組に比べて小さいのは，トリブトフ の濃度が 5 倍であるたるに，可視部の吸収の現われる時 間が短汃いためでめる。

前報》の䋶論に括いて述べたように，綟布を紫外線で 照射した際の黄褐変の発色速度すなわら反射率の減衰速 度は W.M. 照射に比べて著しく大きい。このことは結 局 $b$ が大きく $k$ が小さいこと意味するが，光源が同し W.M. であつても, 呩度が大きい混合溶液の発色につい て，全く同様なことがいかれるのである。

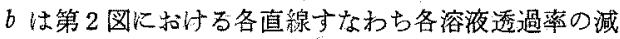
衰の勾配を表わす定数であるが，A 組の混合溶液に比べ て常に大きい。たと辛ば波長 $500 \mathrm{~m} \mu$ のるのにいてい 壳は，A組ては $a=101.4 \quad b=0.063 \quad k=13$ てあるの に対し，B組では $a=97.97 \quad b=0.092 \quad k=4$ である。

多し紫外線を照射した場合， $b$ はさらに大きく，kは ざらに小となるで出る5。

\section{3. 結 論}

編布の光照射による黄褐変が， ロシン，トリプトフ アンのいずれる主として行なわれるのであるらかとい5 ことについて，各々の水溶液拉よびその漉合溶液に W， M. で光照射して，その発色を $X Y Z$ 表色法で比校した そころ， 3 者の主波長が絹の主波長 $576 \mathrm{~m} \mu$ にきか女て 近いということによつて，単なる色相のみから明確な判 断なくだすことは困難であることがわかつた。

しかしなが方縎方るいは混合溶液の主波長特よび光照 射初期以おけるてのずれの現象などが，いずれるまロシ ンとトリプトファンの中間にあること，混合溶液におけ る茼者の濃度比， $\mathrm{pH}$ 执よび照射時間に占つて，主波長 があるいは前者と一致し (A組の場合)，あるいは後者
に近接する（B組の場合）ことなどから考えれば，絹な いし混合溶液の発色に対しては，その情沉に対応して両 者がと的関与することが考慮されてくるのである。

さて混合溶液の可視部に和ける光吸收性は照射時間に よつて三つの段階にわけることができる。すなるち最初 の 0 5 hrではトリプトファンの発色に対するチロシン の減感作用により，光吸収性がほとんど現われない時期 でり(第 1 期)，つぎ 5 10 hr では短波長側におい て急激な增感作用に上る光吸収を生し（第 2 期），最後 の $10 \sim 20 \mathrm{hr}$ では長波長側の增感性む徐々につよくなる

(第3 期)。上述の主波長のづれは $2 \sim 3$ 期の亲化に対 応するるのである。

以上はB組試料についてですり，全期を通じて発色增 感率は 0.5 から 1.7 で增加するか，A組の混合溶液て はトリプトファン源度がB組の1/5であることによつて 発色速度がおそく，第 1 期は $0 \sim 11 \mathrm{hr}$ K，第 2 期は 11 $\sim 20 \mathrm{hr}$ K，第 3 期は $20 \sim 60 \mathrm{hr}$ K相当する。60 $80 \mathrm{hr}$ はB組にはない第 4 期ともいうべき期間で，チロシン， トリブトファンの雨単独液では退色がみられるが，淈合 溶液ではな报発色が進み，そのために增感率は2.3から 3.2 と大きく增加する。

光照射時間 $t(\mathrm{hr})$ と編の反射率岕るいは湿合溶液の 透過率 $T(\%)$ との量的関係比ついて

$$
T=a(t+k)^{-b}
$$

はなる実験式によつて精度よく表現される。

定数 $k$ は陚料出よび発色に用いた照射光源によつて定 宝り，綟の場合は正数であるが溶液では巔数となり，か つ透過光の波長によつて少しく異なる。このことは綟で は光照射前すでにわずかに着色していること，溶液では 照射後もしばらくは発色しないこと竧味する。

$b$ は反射率まるいは透過率の減衰勾配を示す指数で， 光源をW.M. から紫外線にかえた場合，あるいは溶液 の濃度が大きなつた場合にbは增し $k$ は诚少する。 $a$ 虫 100 に近い定数て，光照射とは無関係な固有の色，污 れなどの 2 次的着色によつて定まる。

以上が第 1 報むよび本報を通じて得られた結論の概要 である。発色の主体性についての究極の決定に対しては 黄褐变すなわち可視部における光吸収性の研究だけでは 不充分であることがわかつたので，著者らは現在紫外部 に括ける光吸収についての钼測を行なつている。

\section{文、献}

1) 中村勉, 竹村寿二; 織学誌, 19,894 (1963)

2) " " ; 緎学誌, 18, $294(1962)$

3）吉田箱一，加藤勝；工化，58，274 (1955)

4) " " ; 工化, 58, 667 (1955)

5)岡本奖, 永井忠, 山谷恒夫; 繊学誌, 15, 800(1955)

6) " ; 高分子, 8, 671 (1959) 